\title{
The number of podocyte and slit diaphragm is decreased in experimental diabetic nephropathy ${ }^{1}$
}

\author{
O número de podócitos e fendas diafragmáticas estão alterados \\ na nefropatia diabética
}

\author{
Mauro Masson Lerco², Célia Sperandéo Macedo ${ }^{3}$, Reinaldo José Silva ${ }^{4}$, Daniela de Oliveira Pinheiro ${ }^{5}$, \\ César Tadeu Spadella ${ }^{6}$
}

1. Experimental Laboratory Technique of Surgery- Department of Surgery and Orthopedics. School of Medicine, UNESP - São Paulo State University. Botucatu. Brazil.

2. M.D., Ph.D., Assistant Professor, Department of Surgery and Orthopedics. School of Medicine, UNESP - São Paulo State University. Botucatu. Brazil.

3. M.D., Ph.D., Associate Professor, Department of Pediatric. School of Medicine, UNESP - São Paulo State University. Botucatu. Brazil.

4. Biologist, Ph.D., Assistant Professor, Department of Parasitology, Institute of Biosciences, UNESP - São Paulo State University. Botucatu. Brazil.

5. Biologist, Pos-graduate, Department of Morphology, Institute of Biosciences, UNESP - São Paulo State University. Botucatu. Brazil.

6. M.D., Ph.D., Associate Professor, Department of Surgery and Orthopedics. School of Medicine, UNESP - São Paulo State University. Botucatu. Brazil.

\begin{abstract}
Purpose: To determine the number of podocyte, slit diaphragms, slit diaphragm extensions and GBM thickness in diabetic nephropathy. Methods: Sixty “Rattus Wistar” of both sexes weighing 200-300g were divided in two experimental groups: normal group 10 animals, and alloxan diabetic rats - 50 animals. Alloxan was administered in a single IV dose of $42 \mathrm{mg} / \mathrm{kg}$ body weight. Body weight, water and food intake, diuresis, and blood and urine glucose were determined in both groups before alloxan injection and two weeks, six and twelve months after alloxan injection. Proteinuria was measured at 12 months in both groups. After 12 months animals were sacrificed, and the right kidney processed for electron microscopy. Results: Clear clinical and laboratory signs of severe diabetes were seen, in all alloxan-diabetic rats at all follow-up times. Glomerular basement membrane (GBM) thickening, podocyte number, and slit diaphragm number and extension were determined. GBM of all diabetic rats was significantly thicker (median $=0.29 \mu \mathrm{m}$; semi-interquartile range $=0.065 \mu \mathrm{m}$ ) than in the normal rats $(0.23 \mu \mathrm{m} ; 0.035 \mu \mathrm{m})$. Diabetic rat podocyte number $(8 ; 1)$, slit diaphragm number $(4 ; 1)$, and slit diaphragm extension $(0.021 \mu \mathrm{m} ; 0.00435 \mu \mathrm{m})$ were significantly lower than in normal rats $(11 ; 1)$ and $(7 ; 1.5)$, and $(0.031 \mu \mathrm{m} ; 0.0058 \mu \mathrm{m})$. Diabetic rat proteinuria $(0.060 \mathrm{mg} / 24 \mathrm{~h} ; 0.037 \mathrm{mg} / 24 \mathrm{~h})$ was higher than in normal rats $(0.00185 \mathrm{mg} / 24 \mathrm{~h} ; 0.00055 \mathrm{mg} / 24 \mathrm{~h})$. Conclusion: Experimental diabetes is associated with significant $(\mathrm{p}<0.05)$ changes in podocyte foot process, slit number, slit diaphragm extension, and GBM thickness.
\end{abstract}

Key words: Diabetes Mellitus. Microscopy, Electron. Glomerulonephritis, Membranous.

\section{RESUMO}

Objetivo: Determinar o número de podocitos e fendas diafragmáticas, a extensão das fendas diafragmáticas e a espessura da Membrana Basal Glomerular (MBG) na nefropatia diabética. Métodos: Sessenta “Rattus Wistar” de ambos os sexos, pesando entre 200-300g, foi dividido em dois grupos experimentais: grupo normal 10 animais, e grupo diabético induzido por aloxana - 50 animais. A Aloxana foi administrada em dose única endovenosa de $42 \mathrm{mg} / \mathrm{kg}$ de peso. Medimos o peso, ingestão de água e comida, diurese e glucose sérica e urinária em ambos os grupos antes da injeção de aloxana e 2 (duas) semanas, seis e dose meses após a injeção. A proteinúria foi mensurada aos dose meses em ambos os grupos, no momento do sacrifício, onde removemos o rim direito para estudo ultraestrutural. Resultados: Observamos sinais clínicos e laboratoriais de diabetes severo, nos animais diabéticos aloxânicos em todos os períodos de seguimento. Foi determinado o espessamento da membrana basal glomerular (MBG), número de podocitos, número de fendas diafragmáticas e sua extensão. A membrana basal glomerular do rato diabético mostrou espessamento significativo (mediana $=0.29 \mu \mathrm{m}$; amplitude semi-interquartilica = $0,065 \mu \mathrm{m})$ em relação ao animal normal $(0,23 \mu \mathrm{m} ; 0,035 \mu \mathrm{m})$. O número de podocitos do animal diabético (8; 1$)$, número de fenda diafragmática $(4 ; 1)$, e extensão das fendas diafragmáticas $(0,021 \mu \mathrm{m} ; 0,00435 \mu \mathrm{m})$ foi significativamente menor em relação aos animais normais $(11 ; 1)$ e $(7 ; 1.5)$, e $(0,031 \mu \mathrm{m} ; 0,0058 \mu \mathrm{m})$. A taxa da proteinúria $(0,060 \mathrm{mg} / 24 \mathrm{~h} ; 0,037 \mathrm{mg} / 24 \mathrm{~h})$ foi maior que nos animais normais (0,00185mg/24h; 0,00055mg/24h). Conclusão: O diabetes experimental está associado com significativas alterações $(\mathrm{p}<0,05)$ no número de processos podálicos e fendas diafragmáticas e extensão das fendas diafragmáticas e espessamento da membrana basal glomerular (MBG).

Descritores: Diabetes Mellitus. Microscopia Eletrônica. Glomerulonefrite Membranosa. 


\section{Introduction}

Nowadays, diabetes is considered a worldwide public health problem, either in terms of number of people affected and premature mortality, or the costs involved in controlling it and treating complications. ${ }^{1}$ Diabetic nephropathy develops in 25 to $35 \%$ type 1 and 8 to 10\% type 2 diabetic patients, and is the mean cause of chronic renal disease (CRD) in the USA. ${ }^{2}$ More than $44 \%$ of US patients who start treatment for renal disease are diabetic. ${ }^{3}$

Diabetic nephropathy is one of the most frequent systemic diseases; it causes chronic renal insufficiency in 10 to $15 \%$ of patients starting dialysis in Brazilian metropolitan areas. ${ }^{4}$ There is evidence to show that diabetic nephropathy results from metabolic alterations which occur in the renal glomeruli after long exposure to high glycemic levels (DCCT). ${ }^{5}$

Some studies have evaluated the density and part played by the glomerular visceral epithelial cell or podocyte in diabetic renal disease progression. ${ }^{6,7}$ Podocytes are not able to regenerate, and it has been suggested that a lack or decreased number contribute to the development or progress of diabetic glomerular sclerosis. ${ }^{6}$ Other studies have shown that structural podocyte alterations occur at the initial stages of diabetic nephropathy and that this is related to albumin urinary excretion. ${ }^{8}$

Mifsud et al. ${ }^{9}$ observed a decreased number of slit diaphragm which indicates fusion of the podocyte process and the small number of podocytes in streptozotocin induced diabetic rats. $^{9}$

Based on these considerations the objective of this study was to determine the number of podocyte slit diaphragms, slit diaphragm extensions, and GBM thickness in diabetic nephropathy.

\section{Methods}

\section{Experimental groups}

Sixty male and female Wistar rats were used; they were approximately 3 months old and weighed between 200-300g. They were divided into two experimental groups, normal control group $(\mathrm{N})$ with 10 healthy animals, and diabetic group (D), 50 rats with alloxan-induced diabetes (42mg/kg). Only diabetic rats with glycemia higher than $200 \mathrm{mg} \%$, glycosuria higher than 3000mg\%, and clear signs of severe diabetes 14 days after induction were included in the study. Forty animals were excluded during follow-up because they did not develop severe diabetes or they died during the experiment.

Animals were kept in individual metabolic cages throughout the experiment. The following parameters were evaluated: clinical aspect, weight, urine volume, water intake, fasting blood glucose levels, $12 \mathrm{~h}$ food intake, and $24 \mathrm{~h}$ proteinuria.

All parameters, except proteinuria, were assessed before alloxan injection and two weeks, six months, and twelve months after alloxan injection. Proteinuria was measured at twelve months.

\section{Morphometric studies}

After 12 months the animals were sacrificed. The right kidney from four animals in each group was removed, cut into $3-4 \mathrm{~mm}$ slices and fixed in $1 \%$ glutaraldeyde in phosphate buffer, postfixed in $2 \%$ osmium sulfate in phosphate buffer, $\mathrm{pH} 7.4$ for $2 \mathrm{~h}\left(4^{\circ} \mathrm{C}\right)$, dehydrated in alcohol, and embedded in Epon resin. Blocks were prepared by manual trimming, semithin sections were prepared for light microscopy and ultrathin sections were stained with lead citrate and examined by electron microscopy.

About 30 photomicrographs at 42,000X magnification were made per rat to ensure a minimum of 100 slits per animal were obtained for analysis. The podocyte slit where the linear image of the slit diaphragm was detectable was photographed and counted. Pores where section angle made evaluation of the slit diaphragm impossible were ignored.

There were 115 photomicrographs from Group N and 138 from Group D. Computer image analysis (Qwin Lite 2,5Leica) was used to count podocyte number, slit diaphragm number, slit diaphragm extension, and GBM thickness. All measurements were performed by the same technician, who was unaware of which group the material came from. Data were analysed by the Mann-Whitney test using Sigma-stat 2.0 software to compare all the data.

\section{Results}

Water intake and diuresis in the diabetic group (D) were higher than the normal group $(\mathrm{N}) \mathrm{p}<0.005$. Throughout the experiment diabetes was associated with reduced body weight gain compared to controls $\mathrm{p}<0.005$. Blood glucose levels are shown in Figure 1. Proteinuria medians in diabetic rats were statistically higher than normal rats $(\mathrm{p}<0.001)$. Data are shown in Figure 2. GBM was significantly thicker in diabetic rats than normal rats $(\mathrm{p}<0.001)$. Data are shown in Figure 3. Podocyte and slit diaphragms in diabetic animals were statistically reduced in relation to normal animals $(\mathrm{p}<0.001)$. Data on podocyte number per $2.5 \mu \mathrm{m}$ GBM are shown in Figure4. A significant decrease in filtration slit width was found in the diabetic group $(\mathrm{p}<0.001)$. Data are shown in Figure 5.

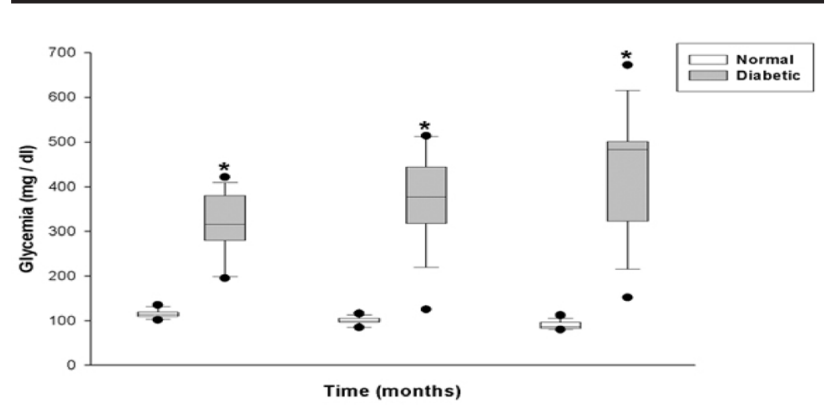

FIGURE 1 - Box plot glycemia levels (mg/dl) in normal (10 animals) at 14 days, and 6 and 12 months after diabetes induction. Each box represents 25-75\% values with median as an internal line, error bar represents $10 \%$ and $90 \%$, and circles represent outliers (5\% and 95\%). Statistics: $\mathrm{p}<0.001$. 


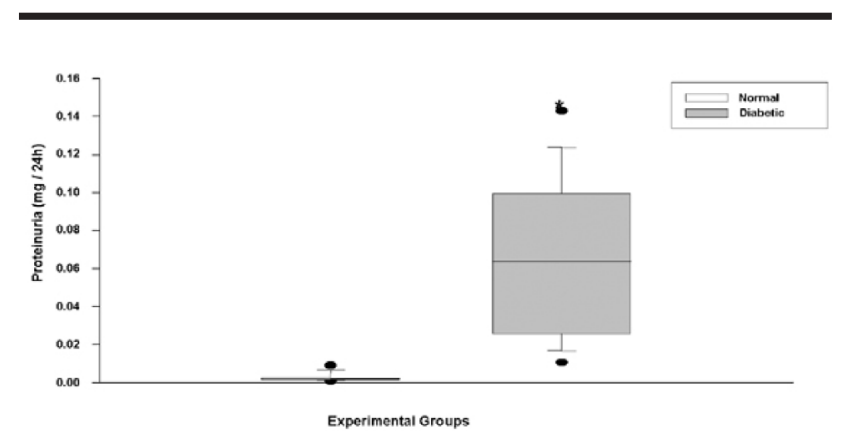

FIGURE 2 - Box plot of proteinuria (mg/24h) in normal rats (10 animals) and diabetic rats (10 animals) 12 months after diabetes induction. Each box represents $25-75 \%$ values with median as an internal line, error bar represents $10 \%$ and $90 \%$, and circles represent outliers (5\% and 95\%). Statistics: $\mathrm{p}<0.001$.

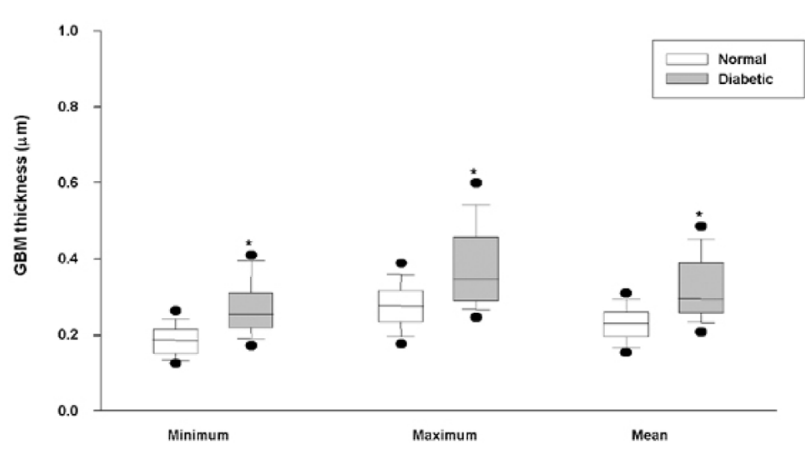

FIGURE 3 - Box plot of median GMB thickness ( $\mu \mathrm{m})$ for normal rats (4 animals) and diabetic rats (4 animals) 12 months after diabetes induction. Each box represents 25-75\% values with median as an internal line, error bar represents $10 \%$ and $90 \%$, and circles represent outliers (5\% and 95\%). Statistics: $\mathrm{p}<0.001$.

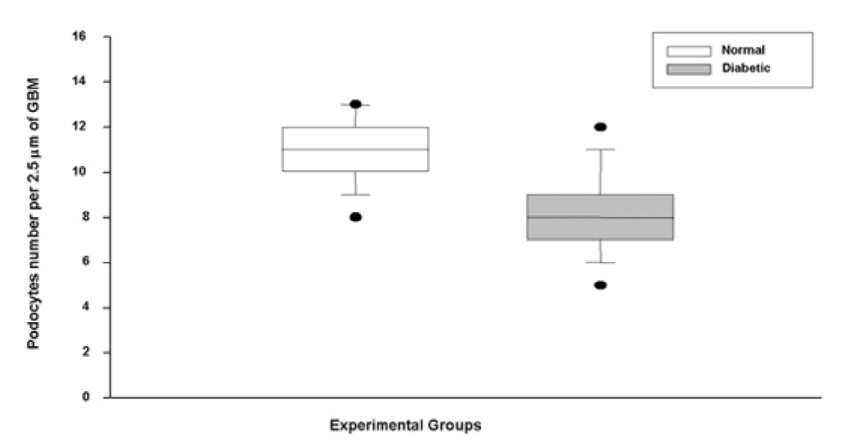

FIGURE 4 - Box plot of median prodocyte number per $2.5 \mu \mathrm{m}$ GMB for normal (4) and diabetic (4) rats 12 months after diabetes induction. Each box represents $25-75 \%$ values with median as an internal line, error bar represents $10 \%$ and $90 \%$, and circles represent outliers (5\% and 95\%). Statistics: $\mathrm{p}<0.001$.

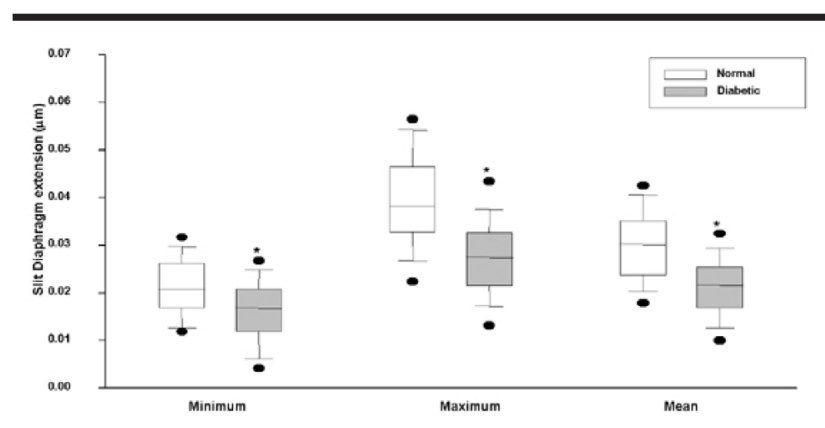

FIGURE 5 - Box plot of median slit diaphragm extension $(\mu \mathrm{m})$ for normal (4) and diabetic (4) rats 12 months after diabetes induction. Each box represents $25-75 \%$ values with median as an internal line, error bar represents $10 \%$ and $90 \%$, and circles represent outliers (5\% and 95\%). Statistics: $\mathrm{p}<0.001$.

It was compared GBM, podocytes, and slits between normal and diabetic rats by electron microscopy at 42,000X magnification. We observed a thicker GBM in diabetic rats than in normal, a lower number of podocytes in the diabetic group and a significant decrease in filtration slit width was found in this group (Figure 6).
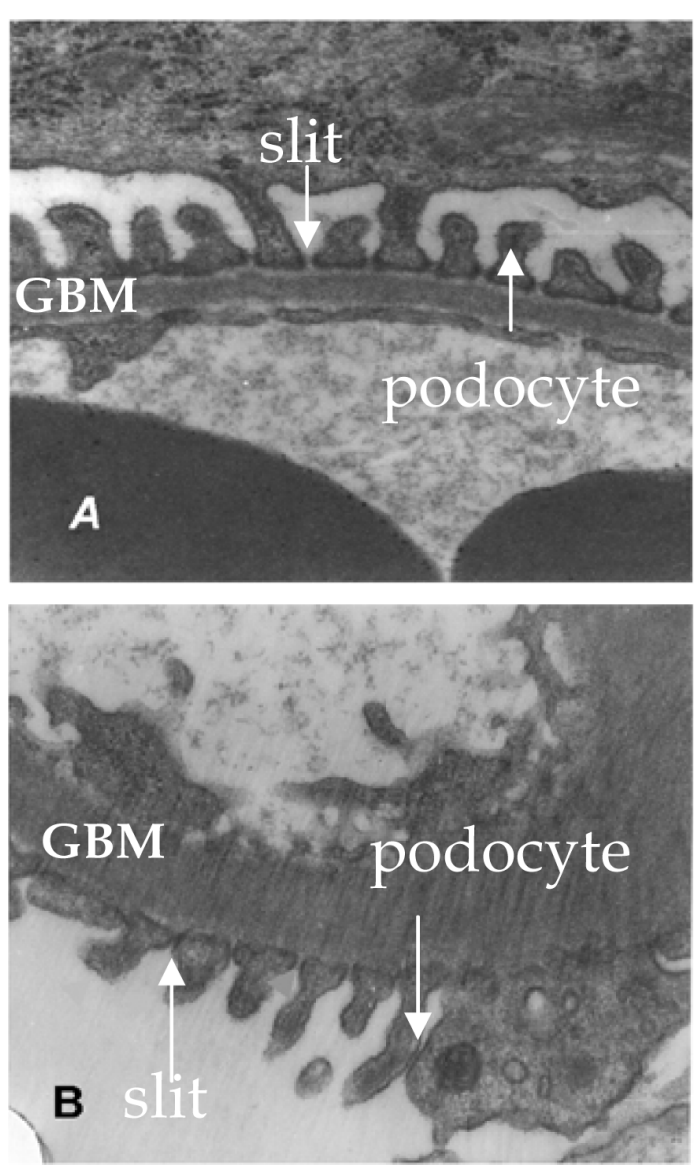

FIGURE 6 - Glomerular basement membrane thickness, podocytesand slit diaphragm. A - Normal rat; B - Diabetic rat. Magnification 42,000 X. 


\section{Discussion}

In this study we show that GBM in diabetic rats was significantly increased in relation to normal rats. Brownlee and Spiro ${ }^{10}$ observed fast GBM synthesis in alloxan diabetic rats, while Fogo ${ }^{11}$ observed that the synthesis overcomes GBM degradation, with accumulation of matrix and thickness. The mechanisms leading to the alterations in GBM metabolism have been clarified by studies focused on the enzymes involved in collagen synthesis and degradation. They found that metalloproteinase activity is decreased by $50 \%$ in diabetic rats. ${ }^{12}$

GBM thickness increases from 6 months after diabetes induction, and its long-term increase in diabetic rats has been demonstrated. ${ }^{13,14}$ Our results confirm these findings.

Proteinuria in diabetic rats has been found after the fourth month of induced diabetes; it is related to molecular and ultrastructural changes in podocytes and slit diaphragm. ${ }^{15}$ We observed less podocytes in diabetic proteinuric rats; this has also been reported in human diabetes at the early stages of nephropathy ${ }^{16}$ and in experimental diabetic nephropathy. ${ }^{9}$

Podocytes are an integral part of the filtration barrier and the loss of podocytes would require the residual cells to cover a larger area of GBM. This could cause foot process widening and reduce the ability of podocytes to remain attached to the GBM with consequent areas of bare GBM, a potential starting point for glomerulosclerosis., ${ }^{71}$ Recent studies in both type 1 and type 2 diabetes $^{7,8}$ have suggested a link between low podocyte number and the development of albuminuria. Mifsud et al. ${ }^{9}$ reported a significative drop in slit filtration number indicative of podocyte foot process broadening in diabetic proteinuric rats after 24 weeks diabetes and an improvement in treated animals. Our data confirm these results in diabetic rats after 48 weeks of diabetes. ${ }^{18}$

Studies show that high glucose on podocytes in vitro causes damage in those cells; these data suggest that glucose-induced podocyte stress could be one factor promoting nephropathy in diabetes. ${ }^{19}$

The slit diaphragm extension was narrower in diabetic rats. Bjorn et al. found that in diabetic patients with proteinuria the slit diaphragm extension was decreased in relation to normoalbuminuric diabetic patients. ${ }^{20}$ The decreased extension of filtration slits seen in this study may play a contributing role in experimental diabetes.

Our data suggest that the diabetic state caused significative structural changes in the glomerular barrier, which consists of GBM, podocytes and slit diaphragm, resulting in proteinuria. These changes contribute to progressive glomerulosclerosis which is a feature of experimental diabetic nephropathy.

\section{Conclusion}

Our data show that diabetes causes structural changes in the glomerular barrier, resulting in proteinuria. These structural changes probably contribute to progressive glomerulosclerosis.

\section{References}

1. Brazilian Society of Diabetes. Consensus. Available from URL: http://www.diabetes.org.br/diabetes/info medicos/ consenso/cons set.html. [2004, Jan 15].

2. Hostetter TH. Diabetic nephropathy. N Engl J Med. 1985; 312: 642-4.

3. Mauer M, Fioretto P, Woredekal Y, Friedman EA. Diabetic nephropathy. In: Schrier RW (editor). Diseases of the kidney and urinary tract. 7ed. Philadelphia: Lippincott Williams \& Wilkins; 2001. p.2083-127.

4. Barros RT, Prado EBA. Rim nas doenças sistêmicas (diabetes, colagenoses, gota). In: Schor N, Srouge M. Nefrologia urologia clínica. São Paulo: Sarvier; 1998. p.76-81.

5. Diabetes Complications and Control Trial (DCCT) Research Group. The effect of diabetes on the development and progression of long-term complications of insulin dependent diabetes mellitus. N Engl J Med. 1993; 329: 977-86.

6. Meyer TW, Bennett PH, Nelson RG. Podocyte number predicts long-term urinary albumin excretion in Pima Indians with type II diabetes and microalbuminuria. Diabetologia. 1999; 42: 1341-4.

7. Vestra MD, Masiero A, Roiler AM, Saller A, Crespaldi AG, Fioretto P. Is podocyte injury relevant in diabetic nephropathy? Studies in patients with type 2 diabetes [complications]. Diabetes 2003; 52(4): 1031-5.

8. White KE, Bilous RW, Marshall SM, Nahas ME, Remuzzi G, Piras G, De Cosmo S, Viberti GC. Podocyte number in normotensive type I diabetic patients with albuminuria. Diabetes. 2002; 51: 3083-9.

9. Mifsud SA, Allen TJ, Bertam JF, Hulthen UL, Kelly DJ, Cooper ME, Wilkinson-Berka JL, Gilbert RE. Podocyte foot process boadening in experimental diabetic nephropathy: amelioration with renin-angiotensin blockade. Diabetologia. 2001; 44: 878-2.

10. Brownlee M, Spiro RG. Glomerular basement membrane metabolism in the diabetic rat. In vivo studies. Diabetes. 1979; 28: 121-5.

11. Fogo AB. Mesangial matrix modulation and glomerulasclerosis. Exp Nephrol. 1999; 7: 147-59.

12. Reckelhoff JF, Tygart VL, Mitias MM, Walcott JL. STZinduced diabetes results in decreased activity of glomerular cathepsin and metallo protease in rats. Diabetes. 1993; 42: 1425-32.

13. Hirose K, Osterby R, Nozawa M, Gundersen HIG. Development of glomerular lesions in experimental longterm diabetes in the rat. Kidney Int. 1982; 21: 889-95.

14. Macedo CS, Silva MD, Spadella CT, Breim LC, Capeletti S, Mercadante MCS, Hernandes D, Macedo AR. Effect of long-term treatment of insulin and/or acarbose on glomerular basement membrane thickening in alloxandiabetic rats. Braz J Med Biol Res. 1996; 29:1329-35.

15. Miner JH, A molecular look at the glomerular barrier. Nephron Exp Nephrol. 2003; 94: 119-22.

16. Steffes MW, Brown DM, Basgen SM. Glomerular basement 
membrane thickness following islet transplantation in the diabetic rat. Lab Invest. 1979; 41: 116-8.

17.Kriz W, Gretz N, Lemley KV. Progression of glomerular disease: is the podocyte the culprit? Kidney Int. 1998; 54: 687-97.

18. Mundel P, Shankland SJ. Podocyte biology and response to injury. J Am Soc Nephrol. 2002; 13: 3005-15.

19. Hoshi S, Shu Y, Yoshida F, Inagaki T, Sonoda J, Watanabe T, Nomoto K, Nagata M. Podocyte injury promotes progressive nephropathy in zucker diabetic fatty rats. Lab Invest. 2002; 82(1): 25-35.
20. Bjorn SF, Bangstad HJ, Hanssen KF, Nyberg G, Walker J, Viberti GC, Osterby R. Glomerular epithelial foot process and filtration slits in IDDM patients. Diabetologia. 1995; 38: 1197-204.

\section{Acknowledgments}

The authors are indebted to Elisa A. Gregório for the contribution in the study.

\section{Correspondence:}

Mauro Masson Lerco

UNESP - Depto. Cirurgia e Ortopedia

R. Rubião Jr, sn

18618-970 Botucatu - SP Brazil

m.masson@fmb.unesp.bror spadella@fmb.unesp.br
Conflict of interest: none

Financial source: none

Received: October 11, 2005

Review: November 10, 2005

Accepted: December 06, 2005

\section{How to cite this article:}

Lerco MM, Macedo CS, Silva RJ, Pinheiro DO, Spadella CT. The number of podocyte and slit diaphragm is decreased in experimental diabetic nephropathy. Acta Cir Bras. [serial on the Internet] 2006 Mar-Apr;21(2). Available from URL: http://www.scielo.br/acb

\section{AVISO AOS AUTORES}

Solicita-se aos autores observarem o estilo e as normas da revista Acta Cirúrgica Brasileira.

Consultar os artigos publicados em fascículos recentes da revista.

Acessar http://www.scielo.br/acb - Instruções aos autores.

Informações adicionais pelo e-mail: sgolden@terra.com.br

\section{RECOMENDAÇÕES AOS AUTORES}

OS DESCRITORES/KEY WORDS são essenciais para a acessibilidade e recuperação dos artigos.

O DeCS (Descritores em Ciências da Saúde) fascilita o acesso a informação e guia os usuários na localização e seleção da informação científica.

Incluir termos, nos descritores, que não estão no DeCS impedem a localização do artigo.

Se os autores desejarem que seus atigos sejam encontrados torna-se imperioso pesquisar no DeCS os termos corretos. Acessar www.bireme.br e clicar em Terminologia em Saúde. A seguir Consulta ao DeCS e por fim Consulta por Palavra nos Idiomas Inglês, Espanhol e Português. 